\title{
Initial development of red and cultivated rice in response to light and air temperature ${ }^{1}$
}

\author{
Eduardo Venske ${ }^{2 *}$, Carlos Eduardo Schaedler ${ }^{3}$, Mariana Peil da Rosa $^{2}$, \\ Carolina Terra Borges ${ }^{2}$, Luis Antonio de Avila ${ }^{4}$, Paulo Dejalma Zimmer ${ }^{2}$
}

\begin{abstract}
Light is an important factor in the cold protection process in plants. The objective of this study was to evaluate the relationship between temperatures and levels of quantity and quality of light on the initial development of rice cultivars and red rice biotypes. Two experiments were conducted, in the laboratory and in the greenhouse, from July to November 2012. The factors studied in experiment I were: temperatures $\left(25^{\circ} \mathrm{C}\right.$ and $\left.18 / 13{ }^{\circ} \mathrm{C}\right)$; cultivars/biotypes (IRGA 424 and PUITÁ INTA-CL/ AV 6716 and AV 6722) and light (white, blue, green, yellow and red, $86 \%$ and $93 \%$ shading and dark). In the second experiment, the factors were seasons (August and November); cultivars/biotypes (IRGA 424 and PUITÁ INTA-CL/AV 6716 and AV 6722) and light (white with cover, white, blue, green, yellow and red, $86 \%$ and $93 \%$ shading). Were evaluated normal seedlings, shoot and root length, shoot and root dry weight and leaf area. The cultivars and biotypes studied have a similar behavior in response to temperature and light during early development. Light, especially the red wavelength, has increased cold tolerance in rice.
\end{abstract}

Index terms: environmental stress, germination, emergency, seedling.

\section{Desenvolvimento inicial de arroz cultivado e vermelho em resposta à luz e temperatura do ar}

\begin{abstract}
RESUMO - A luz é um fator importante nos processos de proteção ao frio nas plantas. O objetivo do trabalho foi avaliar a relação entre temperaturas e quantidade e qualidade de luz sobre o desenvolvimento inicial de cultivares de arroz irrigado e biótipos de arroz vermelho. Foram realizados dois experimentos, sendo eles em laboratório e em casa de vegetação, durante os meses de Julho a Novembro de 2012. Os fatores estudados no experimento I foram: temperaturas $\left(25^{\circ} \mathrm{C} \mathrm{e} 18 / 13{ }^{\circ} \mathrm{C}\right)$; cultivares/biótipos (IRGA 424 e PUITÁ INTA-CL/AV 6716 e AV 6722) e luz (branca, azul, verde, amarela e vermelha, sombreamentos de 86 e $93 \%$ e escuro). No experimento II os fatores foram: épocas (Agosto e Novembro); cultivares/biótipos (IRGA 424 e PUITÁ INTA-CL/ AV 6716 e AV 6722); e luz (branca com recobrimento, branca, azul, verde, amarela e vermelha, sombreamentos de 86 e $93 \%$ ). Avaliou-se plântulas normais, comprimento de parte aérea e raiz, massa da matéria seca da parte aérea e de raízes e área foliar. As cultivares e biótipos estudados têm comportamentos semelhantes em resposta à temperatura e luz durante o desenvolvimento inicial. A luz, especialmente no comprimento de onda do vermelho, apresenta aumento na tolerância ao frio em arroz.
\end{abstract}

Termos para indexação: estresse ambiental, germinação, emergência, plântula.

\section{Introduction}

Low temperature is a major limiting factor for rice productivity in various regions of the world (Hasthanasombut et al., 2011), which, for only occurring frequently during the crop cycle, constitute a serious problem for Rio Grande do Sul, Brazil, mainly in the southern area of the state (Cruz and Millach, 2000).

The origin of rice is tropical, so temperatures below $20^{\circ} \mathrm{C}$ are harmful in a large part of the crop cycle, but in the stages

${ }^{1}$ Submitted on $05 / 28 / 2013$. Accepted for publication on $10 / 28 / 2013$. ${ }^{2}$ Departamento de Fitotecnia, UFPel, Caixa Postal 354, 96010-900 Pelotas, RS, Brasil.

${ }^{3}$ Curso de Agronomia, Universidade Federal do Pampa, 97650-000Itaqui, RS, Brasil. of germination, seedling development and reproduction, damage is more severe (Cruz and Millach, 2000). The occurrence of temperatures below the tolerated minimum damages to the crop seed germination (Mertz et al., 2009) decreasing or delaying it (Martins et al., 2007) and can delay the emergence of seedlings in more than 20 days, in addition to them showing symptoms of chlorosis and slow growth rate (Cruz and Millach, 2000).

In periods with temperature averages below the optimum

${ }^{4}$ Departamento de Fitossanidade, UFPel, Caixa Postal 354, 96010-900 Pelotas, RS, Brasil.

*Corresponding author <eduardo.venske@yahoo.com.br> 
range for crop growth, reduced light intensity can also occur, due to cloudiness. In the rice production areas of the world, periods of low light often occur, which constitutes important constraint to productivity, especially in the tropics (Singh, 2000).

Light is an indispensable feature for plants, being the energy source for their growth and development, however, besides being essential to photosynthesis, it also acts as an environmental signal which, when perceived, triggers changes in plant metabolism and development (Jiao et al., 2007). The effects of light on a community of plants, especially in terms of environmental signaling, are not only related to the magnitude of the photosynthetic photon flux, that is, the amount of light, but also to the direction, duration, and particularly, the quality of light available to plants (Majerowicz and Peres, 2004). The variation in the quality of light in a plant community occurs mainly due to the competition between plants (Merotto et al., 2009), but there are other factors that cause it, such as the presence of dead vegetal covering on the soil.

Besides its importance for growth, development, and environmental perception, studies have shown that light has a connection with a number of other processes in plants, including related to stress tolerance, both biotic and abiotic (Svyatyna and Riemann, 2012). In this regard, light and other environmental stimuli often work together to trigger the development of specific responses in plants (Jiao et al., 2007).

Studies showed that light is an important factor in the cold protection process in plants and is responsible for activation of stress response genes and production of growth regulators on tolerance to low temperatures, reported, for example, in rye (Gray et al., 1997) and wheat (Majláth et al., 2012), which despite being wintry cultures belong to the same botanical family rice, suggesting similar responses in this culture.

The evaluation of the morphology of rice plants in the early stages of development, grown without different conditions of temperature and light, can be useful for initial understanding of crop response against these factors acting together. Such an assessment should provide subsidy as for the feasibility and importance of further studies, such as plant physiology and molecular biology, in understanding these responses against these factors, which together can configure an important step in the development of new strategies to mitigating cold damage in the early stages of irrigated rice culture, mainly from germination to the end of the seedling stage.

Red rice (Oryza sativa L.) is the major weed of irrigated rice (Agostinetto et al., 2001). However, due to its being of the same species of cultivated rice and not subjected to selection processes in the search for adaptability and productivity, is characterized as an important source of genetic variability, which in addition to serving for rice improvement (Malone et al., 2007) may help in understanding plant responses to different environmental factors.

Based on the above, the aim of the study was to evaluate the relationship between temperatures and levels of quantity and quality of light on the early development of two rice cultivars and two red rice biotypes.

\section{Materials and Methods}

Two experiments were conducted, the first in the seed analysis laboratory Flavio Farias Rocha, from the Department of Plant Science, and the second in a greenhouse of the Department of Plant Health, both of the School of Agronomy Eliseu Maciel - FAEM, of the Federal University of Pelotas UFPel, Capão do Leão Campus - RS. The experiments were conducted during the months of July to November 2012. The irrigated rice cultivars used were: IRGA 424 and PUITÁ INTA-CL (PUITÁ), both widely used in the state of RS, and the first being adapted to colder regions of the state, and red rice biotypes AV 6716 and AV 6722, collected in fields of southern RS and multiplied in the previous crop in the lowland area of Palma Agricultural Center (CAP) of UFPel, in the municipality of Capão do Leão - RS.

The first experiment was conducted in factorial $2 \times 4 \times 8$, the main factor being two temperature levels: $25^{\circ} \mathrm{C}$ constant optimum temperature for rice germination (Yoshida, 1981) and alternating temperatures of $18 / 13{ }^{\circ} \mathrm{C}$ for $13 / 11 \mathrm{~h}$ (day/night), simulating sowing conditions in the low temperature season in southern RS. The second factor was cultivar/biotype, and the third was light, with 8 levels, where besides the control (white light), we tested different qualities of light (wavelength) at four levels (blue, green, yellow and red) and amount of light (radiance), in 3 levels (86 and 93\% dark), totaling eight brightness treatments.

This experiment was conducted in a chamber with controlled temperature and photoperiod, type BOD (Biochemical Oxygen Demand). Ten seeds of each cultivar/ biotype were sown in acrylic gerboxes (germination box) with pressed blotter paper substrate, moistened to about 3.0 times its dry weight. The photoperiod was of constant light, at the condition of $25^{\circ} \mathrm{C}$, and in the condition of low temperature, light was provided only during the higher temperature period. The temperature conditions evaluated were obtained by calibrating the growth chambers. The light treatments were imposed by covering each gerbox with cellophane film, of the respective colors, for the treatments of light quality; now for reduction of light intensity, specific meshes were measured with the radiometer $L I-C O R$, inc. model $L I-185 B$, for treatments of 86 and $93 \%$ shade and aluminum foil for the dark condition (Table 1). To minimize other effects of covering the gerboxes, in addition to light, the controls were covered with 
colorless cellophane. The experimental design was arranged in bands, each BOD housed one temperature treatment and each shelf one light treatment. Three replications were used, each gerbox considered a replicate. Among cultivars/biotypes and replications the randomization was complete.

At 21 days after sowing, the evaluation was carried out in the experiment of the following variables: normal seedlings, length of shoot and root, leaf area and dry weight of shoot and root. Only seedlings considered normal were evaluated in the other variables. Were considered normal the seedlings with developed and proportional shoot and root, according to criteria of the Rules for Seed Analysis - RAS (Brasil, 2009), the result was expressed in numbers. In the variables shoot and root length, the seedlings were measured with the aid of a millimeter ruler, and for the root, the main part was considered, and the average value per seedling was expressed in millimeters. For determination of the leaf area, the shoot of the seedlings were highlighted, using the electronic determiner LI-COR Model Li 3100 held a joint reading of all seedlings per replication, dividing the result by the number of normal seedlings of each experimental unit, and the result expressed in square centimeters per seedling. For the variables of shoot and root dry weight, these tissues of all seedlings in each replicate were collected in paper bags and placed in an oven set at $65^{\circ} \mathrm{C}$ for a period of 72 hours when they were taken, cooled in dehumidifier and weighed on a precision balance. The result was expressed in milligrams per seedling.
The second experiment was conducted in a greenhouse in a $2 \times 4 \times 8$ factorial scheme, where the main factor was sowing season: first half of August, which showed average daily temperature of $25^{\circ} \mathrm{C}$ and a minimum daily average of $10^{\circ} \mathrm{C}$, and the second half of November, with daily average of $35^{\circ} \mathrm{C}$ and a minimum daily average of $29^{\circ} \mathrm{C}$. The second factor was cultivar/biotype, with the same cultivars/biotypes of the first experiment, and the third factor was light, which consisted of 8 different levels of quality and quantity of light [white light without cellophane, white light (with cellophane) blue, green, yellow and red and shadings of $86 \%$ and $93 \%$ ].

The sowing of cultivars/biotypes was performed in vessels with a volume capacity of $200 \mathrm{~mL}$, filled with soil taken from rice crop areas. Five seeds were sown per pot and, after emergence, the plants were thinned, leaving only three seedlings per experimental unit. The pots were placed into plastic trays, which were maintained with approximately $3.0 \mathrm{~cm}$ of water, thus allowing irrigation by capillarity. For the light treatments, the pots were covered, in the volumetric space that seedlings would possibly occupy, with cellophane films of different colors or mesh of different levels of shading, depending on the treatment, over wire arches. Cellophane was changed every 02 days. The design was in bands, each light treatment being represented by a tray with all cultivars/biotypes and four replications. Within each tray, the randomization was complete. Concurrently with the conduction of the experiment, daily measurements of the temperatures for each light treatment were performed between 9:00 am and 10:00 am (Table 1 and Figure 1).

Table 1. Characterization of the treatments of growth chamber and greenhouse experiments regarding light and temperature.

\begin{tabular}{|c|c|c|c|c|}
\hline \multirow[t]{2}{*}{ Light treatment } & \multirow{2}{*}{$\begin{array}{l}\text { Range of wave } \\
\text { length }^{1}(\mathrm{~nm})\end{array}$} & \multirow{2}{*}{$\begin{array}{l}\text { Attenuation of } \\
\text { light qty }(\%)\end{array}$} & \multicolumn{2}{|c|}{$\begin{array}{l}\text { Average temperatures for } \\
\text { greenhouse exp. }\left({ }^{\circ} \mathrm{C}\right)\end{array}$} \\
\hline & & & 1st Season & 2nd Season \\
\hline White with cover ${ }^{3,4}$ & $400-740$ & 0 & 25 & 38 \\
\hline White without cover ${ }^{4}$ & $400-740$ & 0 & 24 & 32 \\
\hline Blue $e^{3,4}$ & $425-490$ & - & 25 & 37 \\
\hline Green $^{3,4}$ & $490-560$ & - & 25 & 38 \\
\hline Yellow 3,4 & $560-585$ & - & 25 & 36 \\
\hline $\operatorname{Red}^{3,4}$ & $640-740$ & - & 25 & 37 \\
\hline Mesh $1^{3,4}$ & $400-740$ & 86 & 23 & 32 \\
\hline $\operatorname{Mesh} 2^{3,4}$ & $400-740$ & 93 & 24 & 31 \\
\hline $\operatorname{Dark}^{3}$ & - & 100 & - & - \\
\hline Mean & & & 25 & 35 \\
\hline
\end{tabular}

${ }^{1}$ According to Majerowicz (2004); ${ }^{2}$ Calculated after radiometer reading; ${ }^{3}$ Growth chamber exp.; ${ }^{4}$ Greenhouse exp.

The variables evaluated in this experiment were: shoot and root length, leaf area, and shoot and root dry weight, which were measured identically to the experiment in growth chamber at 16 days after sowing, after removing the plants from the pots and washing the soil off their root.
With the aid of the radiometer $L I-C O R$, inc. model $L I$ $185 \mathrm{~B}$, the irradiance of light in each environment in the two experiments was read (Table 1). The results were tabulated and subjected to analysis of variance. After the detection of interactions between factors, Fischer's LSD means test was 
held at $5 \%$ probability of error. Depending on the purpose of the study, were presented only the variables where interaction was significant between temperature and light, being omitted from the results when the interaction occurred in only one of these factors with cultivars/biotypes or when there was no interaction between the factors.

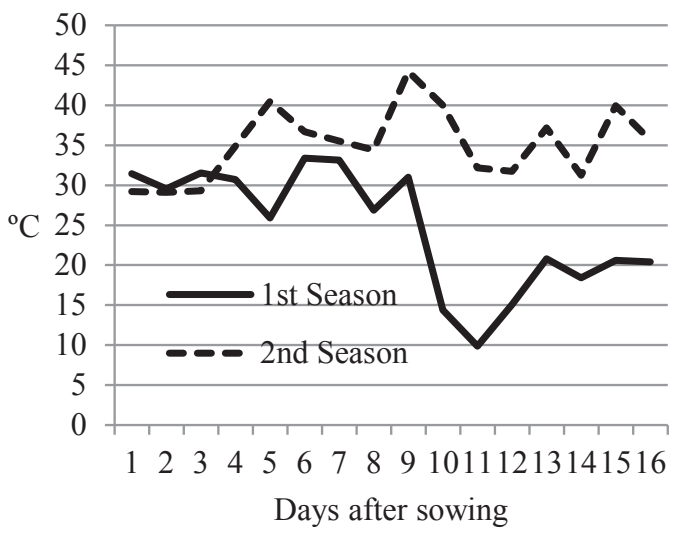

Figure 1. Daily temperatures, average readings of all light treatments, of the greenhouse experiment.

\section{Results and Discussion}

The effects of the interaction temperature $\mathrm{x}$ cultivar/ biotype $x$ light were significant for the variable root length (CR), in the experiment conducted in a growth chamber (Table 2). In general, lower values were observed in the condition of $18 / 13{ }^{\circ} \mathrm{C}$ when compared to constant $25{ }^{\circ} \mathrm{C}$ temperature, except for the dark treatment, where the IRGA 424 cultivar and red rice biotype AV 6722 showed no difference for this variable between temperatures.

The CR showed variation between the means observed in treatments for the cultivars and biotypes. IRGA 424 and PUITÁ INTA-CL, at $18 / 13{ }^{\circ} \mathrm{C}$, showed higher values in the dark treatment and lower values under the white light treatment. Now, for AV 6716 and AV 6722, at this temperature, the higher values also occurred in the dark, however, the lowest values were for the yellow and green light treatments, not differing from the white, blue and red light treatments.

Table 2. Root length of irrigated rice cultivars and red rice biotypes in function of temperatures and light, evaluated at 21 days after sowing in a growth chamber.

\begin{tabular}{|c|c|c|c|c|c|c|c|c|}
\hline \multirow{3}{*}{ Treatment } & \multicolumn{8}{|c|}{ Root length $(\mathrm{cm})$} \\
\hline & \multicolumn{4}{|c|}{$13 / 18^{\circ} \mathrm{C}$} & \multicolumn{4}{|c|}{$25^{\circ} \mathrm{C}$} \\
\hline & IRGA 424 & PUITÁ & AV 6716 & AV 6722 & IRGA 424 & PUITÁ & AV 6716 & AV 6722 \\
\hline White light $(\mathrm{t})$ & $0.01 \mathrm{Ad}^{1}$ & $0.63 \mathrm{Acd}$ & 0.80 Acde & $0.53 \mathrm{Ad}$ & $4.73 \mathrm{Ba}^{1 *}$ & 4.40 Bab* & $4.57 \mathrm{Bb}^{*}$ & $6.23 \mathrm{Aab}^{*}$ \\
\hline Blue light & 0.97 Acd & $1.30 \mathrm{Abcd}$ & 1.30 Abcde & 1.37 Acd & $4.67 \mathrm{ABa}^{*}$ & $4.83 \mathrm{ABab}^{*}$ & 4.10 Bbc* & $5.47 \mathrm{Aabc}^{*}$ \\
\hline Green light & $0.53 \mathrm{Ad}$ & $0.90 \mathrm{Abcd}$ & 0.67 Ade & $0.37 \mathrm{Ad}$ & $3.50 \mathrm{Bb}^{*}$ & $3.76 \mathrm{ABb}^{*}$ & $3.20 \mathrm{Bc}^{*}$ & $4.97 \mathrm{Ac}^{*}$ \\
\hline Yellow light & $0.17 \mathrm{Ad}$ & 0.83 Acd & $0.60 \mathrm{Ae}$ & $0.70 \mathrm{Ad}$ & $5.00 \mathrm{Aa}^{*}$ & $5.53 \mathrm{Aa}^{*}$ & 4.60 Ab* & $5.53 \mathrm{Aabc}^{*}$ \\
\hline Red light & $0.46 \mathrm{Ad}$ & 0.80 Acd & 1.10 Abcde & $0.83 \mathrm{Ad}$ & $5.03 \mathrm{Aa}^{*}$ & 4.70 $\mathrm{Aa}^{*}$ & 4.16 Abc* & $5.23 \mathrm{Aabc}^{*}$ \\
\hline Shading $86 \%$ & $2.20 \mathrm{Ab}$ & $2.06 \mathrm{Ab}$ & $1.93 \mathrm{Aabc}$ & $2.37 \mathrm{Abc}$ & $4.46 \mathrm{Aab}^{*}$ & 4.26 Aab* & 4.26 Abc* & 5.20 Aabc* \\
\hline Shading 93\% & $1.90 \mathrm{Abc}$ & $2.00 \mathrm{Abc}$ & 1.83 Aabcd & $3.00 \mathrm{Ab}$ & 4.10 ABab* & $3.70 \mathrm{Bb}^{*}$ & $4.33 \mathrm{ABc}^{*}$ & $5.17 \mathrm{Abc*}$ \\
\hline Dark & $3.87 \mathrm{BCa}$ & $4.10 \mathrm{Ba}$ & $2.87 \mathrm{Ca}$ & $7.40 \mathrm{Aa}$ & $4.37 \mathrm{Bab}^{\mathrm{ns}}$ & $5.53 \mathrm{ABa}^{*}$ & $6.67 \mathrm{Aa}^{*}$ & $6.40 \mathrm{Aa}^{\mathrm{ns}}$ \\
\hline Mean & & & & & 17 & & & \\
\hline C.V. $(\%)$ & & & & & 83 & & & \\
\hline
\end{tabular}

${ }^{1}$ Means preceded by lowercase letters compared in the columns and followed by uppercase letters in the rows, when distinct, within each temperature, differ among themselves. ${ }^{\text {ns }}$ and * represent respectively non significant and significant between the same cultivars/biotypes and the same light treatment, but at different temperatures, by Fisher's LSD test $(\mathrm{p} \leq 0.05)$.

For the temperature of $25^{\circ} \mathrm{C}$, IRGA 424 showed a higher value of $\mathrm{CR}$ in the red light treatment, not differing from the other treatments, except for green light. For the cultivar PUITÁ INTA-CL, the dark treatment had the highest value, and the treatment with $93 \%$ shading showed the lowest, not differing from the green light. The red rice biotypes also showed high CR value in the dark, but lower values were observed for green light and 93\% shading.

Generally, in the absence of light (dark) occurred the highest root lengths at the two temperatures, however, most notably when under low temperature; and in the green light treatment occurred the lowest values at $25^{\circ} \mathrm{C}$ temperature.

For the variables: number of normal seedlings (NR), shoot length (CPA), shoot dry weight (MSPA) and root dry weight (MSR) there was interaction between temperature and light (Table 3). At low temperature, smaller values for all variables occurred, regardless of light, except for NR, which under dark and shadings had no difference between temperatures. 
Table 3. Mean values, per gerbox, of the number of normal seedlings, and per seedling of shoot length (CPA), in centimeters, dry weight of shoot (MSPA) and root (MSR), in milligrams, of irrigated rice cultivars and red rice biotypes, depending on temperature and light, evaluated at 21 days after sowing.

\begin{tabular}{|c|c|c|c|c|c|c|c|c|}
\hline \multirow[t]{2}{*}{ Treatment } & \multicolumn{2}{|c|}{$\begin{array}{c}\text { Number of normal } \\
\text { seedlings }\end{array}$} & \multicolumn{2}{|c|}{$\begin{array}{c}\text { CPA } \\
\left(\mathrm{cm} \cdot \text { seedling }^{-1}\right)\end{array}$} & \multicolumn{2}{|c|}{$\begin{array}{c}\text { MSPA } \\
\left(\mathrm{mg} . \text { seedling }^{-1}\right)\end{array}$} & \multicolumn{2}{|c|}{$\begin{array}{c}\text { MSR } \\
\left(\mathrm{mg}^{\text {seedling }}{ }^{-1}\right)\end{array}$} \\
\hline & $18 / 13{ }^{\circ} \mathrm{C}$ & $25^{\circ} \mathrm{C}$ & $18 / 13^{\circ} \mathrm{C}$ & $25^{\circ} \mathrm{C}$ & $18 / 13^{\circ} \mathrm{C}$ & $25^{\circ} \mathrm{C}$ & $18 / 13^{\circ} \mathrm{C}$ & $25^{\circ} \mathrm{C}$ \\
\hline White light & $2.67 \mathrm{Bd}^{*}$ & $8.58 \mathrm{Aa}$ & $0.34 \mathrm{Bd}$ & $6.17 \mathrm{Ab}$ & $0.53 \mathrm{Bc}$ & $4.07 \mathrm{Aa}$ & $0.34 \mathrm{Bcd}$ & $2.67 \mathrm{Aa}$ \\
\hline Blue light & $4.75 \mathrm{Bc}$ & $8.42 \mathrm{Aa}$ & $0.70 \mathrm{Bd}$ & $6.55 \mathrm{Aab}$ & $1.50 \mathrm{Bab}$ & $4.23 \mathrm{Aa}$ & $0.75 \mathrm{Bbc}$ & $2.48 \mathrm{Aa}$ \\
\hline Green light & $3.83 \mathrm{Bcd}$ & $7.75 \mathrm{Aa}$ & $0.45 \mathrm{Bd}$ & $6.07 \mathrm{Ab}$ & $0.38 \mathrm{Bc}$ & $3.50 \mathrm{Aabc}$ & $1.41 \mathrm{Ba}$ & $2.25 \mathrm{Aab}$ \\
\hline Yellow light & $3.83 \mathrm{Bcd}$ & $8.42 \mathrm{Aa}$ & $0.87 \mathrm{Bcd}$ & $6.10 \mathrm{Ab}$ & $0.32 \mathrm{Bc}$ & $4.03 \mathrm{Aa}$ & $0.22 \mathrm{Bd}$ & $2.62 \mathrm{Aa}$ \\
\hline Red light & $4.00 \mathrm{Bc}$ & $8.83 \mathrm{Aa}$ & $0.65 \mathrm{Bcd}$ & 6.51 Aab & $0.65 \mathrm{Bbc}$ & $3.91 \mathrm{Aab}$ & $0.88 \mathrm{Bb}$ & $2.25 \mathrm{Aab}$ \\
\hline $86 \%$ shading & $8.42 \mathrm{Aa}$ & $7.95 \mathrm{Aa}$ & $1.98 \mathrm{Bab}$ & $5.04 \mathrm{Ac}$ & 1.25 Babc & $2.84 \mathrm{Ac}$ & $0.35 \mathrm{Bcd}$ & $1.45 \mathrm{Ac}$ \\
\hline $93 \%$ shading & $7.42 \mathrm{Aa}$ & $7.92 \mathrm{Aa}$ & $1.57 \mathrm{Bbc}$ & $4.49 \mathrm{Ac}$ & $0.89 \mathrm{Bbc}$ & $3.01 \mathrm{Abc}$ & $0.87 \mathrm{Bb}$ & $1.86 \mathrm{Abc}$ \\
\hline Dark & $8.50 \mathrm{Aa}$ & $8.75 \mathrm{Aa}$ & $2.58 \mathrm{Ba}$ & $6.99 \mathrm{Aa}$ & $2.00 \mathrm{Ba}$ & $4.28 \mathrm{Aa}$ & $0.41 \mathrm{Bcd}$ & $2.32 \mathrm{Aa}$ \\
\hline Mean & \multicolumn{2}{|c|}{6.90} & \multicolumn{2}{|c|}{3.57} & \multicolumn{2}{|c|}{2.34} & \multicolumn{2}{|c|}{1.44} \\
\hline C.V. (\%) & \multicolumn{2}{|c|}{22.85} & \multicolumn{2}{|c|}{28.14} & \multicolumn{2}{|c|}{49.24} & \multicolumn{2}{|c|}{38.53} \\
\hline
\end{tabular}

*Means preceded by lowercase letters compared in the columns and followed by uppercase letters in the rows, for the same variable, when distinct, differ by Fisher's LSD test $(\mathrm{p} \leq 0.05)$.

In $\mathrm{NR}$, at $18 / 13{ }^{\circ} \mathrm{C}$ the lowest value was observed under white light, and the highest under shadings and dark, which did not differ, since at $25^{\circ} \mathrm{C}$ none of the light treatments differed. For CPA, the dark resulted in the highest values at the two temperatures, not differing from $86 \%$ shading, at $18 / 13^{\circ} \mathrm{C}$, and blue and red lights at $25^{\circ} \mathrm{C}$. In this same variable, at $18 / 13^{\circ} \mathrm{C}$, treatments with lower values by classes of means did not stand out, but at $25^{\circ} \mathrm{C}$, levels of shading resulted in the lowest CPAs. As for MSPA, the dark treatment once again caused the highest values at the two temperatures. Under low temperature, it did not differ from blue and $86 \%$ shading, which had white, green and yellow lights in the lower classes of means. On the other hand, at $25^{\circ} \mathrm{C}$, dark only differed from the shading treatments, which showed the lowest values.

The variable MSR, especially at $18 / 13{ }^{\circ} \mathrm{C}$, was the exception, where the highest value did not occur under dark treatment, but under green light. At this same temperature, the lowest MSR occurred under yellow light. Now at the condition of $25^{\circ} \mathrm{C}$, dark was again in the highest mean class, but the highest value occurred under white light, differing from shading by 93 and $86 \%$, the latter being the treatment that showed the lowest value. In general, MSR values were not proportional to $\mathrm{CR}$ values, in the light treatments.

Low temperatures cause, in most cases, inhibition of root growth, reducing the supply of water, nutrients and growth regulators produced by this organ, such as cytokinins, to the shoot, which represents one of the main factors that lead to productivity losses by cold (Vaseva et al., 2009). On the other hand, the reduction in growth, not only of root, but also of shoot, evidenced at low temperatures, is also regarded as a response to various stress types, essential for the maintenance of hormone balance in the plant (Majláth et al ., 2012).

The behavior of higher root growth in the dark, or shading condition, is the opposite of what is expected, due to the growth of the shoot being set in a drain, which limits root growth (Majerowicz and Peres, 2004), and when this prioritization does not occur, there may be a lack of reserves so the seedling can grow to avoid the lack of light in the natural environment. Therefore, since the values of this variable in the dark treatment are even higher when at low temperatures, it is evident, similarly to the hypotheses of this study, that losses due to the lack of light are also enhanced under cold conditions.

The contrast observed among the light and dark treatment, or shadings, in the values of the variables CPA and MSPA, is greater in the low temperature condition, where at $25{ }^{\circ} \mathrm{C}$ the difference in CPA between white light and dark is about $13 \%$, now at $18 / 13{ }^{\circ} \mathrm{C}$ this difference exceeds $650 \%$. This result emphasizes that, in addition to shading, the greater growth induced by of lack light, other factors contribute to the differences between growth under light and dark (or shading) when at temperatures below optimum for plant growth. Among them the aforementioned phenomenon of reduced growth aiming the adjustment to stress (Penfield, 2008), in this case low temperature stress, which proved to be active in the presence of light. In researches with barley, a higher freezing tolerance was observed in plants with smaller stature, which were acclimated at low temperature and higher light intensity, in contrast to those that were acclimated at the same temperature, but at lower light, which presented a higher growth, but 52\% less tolerance to freezing (Gray et al., 1997).

As for the experiment in a greenhouse, although the average temperature of the first season was $25^{\circ} \mathrm{C}$, there were 
daily temperatures suboptimal for the full development of rice seedlings, which are between 20 and $25{ }^{\circ} \mathrm{C}$ (Yoshida, 1981), with greater emphasis on the period between the 10th and 12 th day of the experiment (Figure 1).

The variable shoot length (CPA) showed interaction between the factors studied (Table 4). The cultivars/biotypes in most light treatments showed lower value of this variable in the first season, possibly due to the lower average temperature occurred (Table 1), however, there was an exception in the treatments with blue, yellow and red light, where the latter did not differ between seasons for any of the cultivars or biotypes.

Table 4. Length of shoot per seedling in two growing seasons of rice cultivars and red rice biotypes in function of temperature and light, evaluated at 16 days after sowing and grown in a greenhouse.

\begin{tabular}{|c|c|c|c|c|c|c|c|c|}
\hline \multirow{3}{*}{ Treatment } & \multicolumn{8}{|c|}{ Shoot length $(\mathrm{cm})$} \\
\hline & \multicolumn{4}{|c|}{ First season } & \multicolumn{4}{|c|}{ Second season } \\
\hline & IRGA 424 & PUITÁ & AV 6716 & AV 6722 & IRGA 424 & PUITÁ & AV 6716 & AV 6722 \\
\hline White light & $9.47 \mathrm{Cd}^{*}$ & $11.80 \mathrm{ABc}$ & $9.95 \mathrm{BCc}$ & $12.28 \mathrm{Ae}$ & $14.26 \mathrm{Bb}^{*}$ & $18.52 \mathrm{Ab}^{*}$ & $13.90 \mathrm{Bb}^{*}$ & $17.86 \mathrm{Ab}^{*}$ \\
\hline White light (c/f) & $13.72 \mathrm{Cab}$ & $16.07 \mathrm{ABa}$ & 14.17 BCa & 16.51 Abcd & $10.57 \mathrm{Ac}^{*}$ & $11.77 \mathrm{Ad}^{*}$ & $9.58 \mathrm{Ad}^{*}$ & $11.09 \mathrm{Ad}^{*}$ \\
\hline Blue light & 12.33 Babc & $13.33 \mathrm{Bbc}$ & $13.26 \mathrm{Ba}$ & 18.25 Aab & $10.74 \mathrm{Ac}^{\mathrm{ns}}$ & $11.87 \mathrm{Ad}^{\mathrm{ns}}$ & 11.46 $\mathrm{Acd}^{\mathrm{ns}}$ & 12.74 Acd* \\
\hline Green light & $12.31 \mathrm{Cabc}$ & $15.26 \mathrm{ABab}$ & $13.05 \mathrm{BCa}$ & 16.26 Abcd & $9.47 \mathrm{Bc}^{*}$ & $11.24 \mathrm{Bd}^{*}$ & $9.62 \mathrm{Bd}^{*}$ & $13.92 \mathrm{Ac}^{*}$ \\
\hline Yellow light & 13.47 Bab & $16.97 \mathrm{Aa}$ & $14.55 \mathrm{Ba}$ & 16.96 Aabc & $15.59 \mathrm{Bb}^{\mathrm{ns}}$ & $19.09 \mathrm{Ab}^{*}$ & $12.81 \mathrm{Cbc}^{\mathrm{ns}}$ & $19.16 \mathrm{Ab}^{*}$ \\
\hline Red light & $14.14 \mathrm{Ba}$ & $16.25 \mathrm{Ba}$ & $14.18 \mathrm{Ba}$ & $18.73 \mathrm{Aa}$ & $14.97 \mathrm{Bb}^{\mathrm{ns}}$ & $16.39 \mathrm{Bc}^{\mathrm{ns}}$ & $14.33 \mathrm{Bb}^{\mathrm{ns}}$ & $18.82 \mathrm{Ab}^{\mathrm{ns}}$ \\
\hline $86 \%$ shading & $10.24 \mathrm{Bcd}$ & $13.29 \mathrm{Abc}$ & 12.57 Aab & 14.78 Acd & $19.86 \mathrm{Ba}^{*}$ & 23.32 $\mathrm{Aa}^{*}$ & $19.20 \mathrm{Ba}^{*}$ & $24.05 \mathrm{Aa}^{*}$ \\
\hline $93 \%$ shading & $8.87 \mathrm{Bd}$ & $12.93 \mathrm{Ac}$ & $10.50 \mathrm{Bbc}$ & $14.65 \mathrm{Ad}$ & 19.34 $\mathrm{Ba}^{*}$ & $23.42 \mathrm{Aa}^{*}$ & $18.40 \mathrm{Ba}^{*}$ & $25.34 \mathrm{Aa}^{*}$ \\
\hline Mean & & & & & & & & \\
\hline C.V. (\%) & & & & & & & & \\
\hline
\end{tabular}

${ }^{1}$ Means preceded by lowercase letters compared in the columns and/or followed by uppercase letters in the rows, when distinct, within each temperature, differ among themselves. ${ }^{\mathrm{ns}}$ and * represent respectively non difference and significant difference, and compare means between the same cultivars/biotypes and the same light treatment, but at different temperatures, all by Fisher's LSD test $(p \leq 0.05)$.

In both seasons, cultivars and biotypes showed similar behavior for the treatments. In the first season, the red light treatment showed higher values for IRGA 424 and AV 6722, and yellow light for PUITÁ INTA-CL and AV 6716, however, in general, there were no significant differences between light qualities. Still, for IRGA 424, the lowest CPA was under 93\% shading, but for the other genotypes it was under white light. In the second season, the highest CPAs occurred under the two shading treatments, which differed from all others. As for the lower values for the cultivars they occurred in the green treatment, however, they did not differ from white light with film and blue light. For red rice biotypes, lower values were observed under white light with film, which for AV 6716 did not differ from blue and green lights and for AV 6722 did not differ only from blue light.

For CR, MSPA, MSR and leaf area, each variable showed differential behavior in function of temperature and light (Table 5). Only in the treatments white light without film, green and $93 \%$ shading, there was a growth pattern for all variables which were higher in the highest temperature (second season) for white light and 93\% shading and, curiously, higher under lower temperature (first season) for the green light.

The CR, in the first season, was higher under red light, differing only from white light, and from the treatments under
86 and $93 \%$ shading, the latter being the treatment that caused lesser value. In the second season, the white light showed a higher value for the variable $\mathrm{CR}$, differing from other treatments. Also, in this season, the green and white light with covering were the treatments that had the lowest values, respectively, not differing among themselves.

For the variable MSPA, yellow light caused greater mass, which did not differ from white light with covering, green and red lights, in the first season, where white light and shadings were the treatments with the lowest values. In the second season, again yellow light, not differing from white light and $86 \%$ shading, caused greater MSPA. Blue and green lights were the treatments that caused the lowest values at this time. As for MSR, in the first time the four levels of light quality did not differ among themselves, and shadings caused the lowest values, along with the two treatments of white light. Now, in the second season, quite prominently, white and green light caused, respectively, the highest and lowest values in the variable, both differing from the others. Regarding leaf area, in the first season blue and red lights caused the highest values, and white light caused the lowest, and in the second season, shadings caused greater leaf area, and lower values occurred under white light with film and green light. 
Table 5. Mean values of root length (CR), dry weigth of shoot (MSPA), root (MSR) and leaf area, in two seasons, of rice cultivars and red rice biotypes in function of temperature and light, evaluated at 16 days after sowing, grown in a greenhouse.

\begin{tabular}{|c|c|c|c|c|c|c|c|c|}
\hline \multirow[t]{2}{*}{ Treatment } & \multicolumn{2}{|c|}{$\mathrm{CR}(\mathrm{cm})$} & \multicolumn{2}{|c|}{ MSPA (mg.seedling ${ }^{-1}$ ) } & \multicolumn{2}{|c|}{ MSR (mg.seedling ${ }^{-1}$ ) } & \multicolumn{2}{|c|}{$\begin{array}{c}\text { Leaf area } \\
\left(\mathrm{cm}^{2} \text {.seedling }{ }^{-1}\right)\end{array}$} \\
\hline & 1st Season & 2nd Season & 1st Season & 2nd Season & 1st Season & 2nd Season & 1st Season & 2nd Season \\
\hline White light & $11.39 \mathrm{Bbc}^{*}$ & $16.26 \mathrm{Aa}$ & $12.70 \mathrm{Bd}$ & $28.65 \mathrm{Aab}$ & $10.64 \mathrm{Bcd}$ & $26.25 \mathrm{Aa}$ & $1.38 \mathrm{Bd}$ & $2.91 \mathrm{Ab}$ \\
\hline White light $\mathrm{c} / \mathrm{r}$ & 13.17 Aa & $8.83 \mathrm{Be}$ & $19.44 \mathrm{Aa}$ & 17.16 Ad & $10.96 \mathrm{Abcd}$ & $11.16 \mathrm{Ac}$ & $2.00 \mathrm{Abc}$ & $1.33 \mathrm{Be}$ \\
\hline Blue light & 12.52 Aab & $11.91 \mathrm{Ac}$ & 16.15 Abc & $13.69 \mathrm{Ae}$ & 12.31 Aabc & $11.54 \mathrm{Ac}$ & $2.99 \mathrm{Aa}$ & $1.92 \mathrm{Bd}$ \\
\hline Green light & $12.94 \mathrm{Aa}$ & $8.30 \mathrm{Be}$ & $18.13 \mathrm{Aab}$ & $14.03 \mathrm{Be}$ & $14.18 \mathrm{Aa}$ & $7.45 \mathrm{Be}$ & $2.27 \mathrm{Ab}$ & $1.35 \mathrm{Be}$ \\
\hline Yellow light & $13.27 \mathrm{Aa}$ & $2.47 \mathrm{Ac}$ & $19.78 \mathrm{Ba}$ & $30.89 \mathrm{Aa}$ & 13.62 Bab & $18.66 \mathrm{Ab}$ & $1.92 \mathrm{Bbc}$ & $2.46 \mathrm{Ac}$ \\
\hline Red light & $13.48 \mathrm{Aa}$ & $10.57 \mathrm{Bd}$ & $19.48 \mathrm{Aa}$ & $22.24 \mathrm{Ac}$ & $13.97 \mathrm{Ba}$ & $16.82 \mathrm{Ab}$ & $2.71 \mathrm{Aa}$ & $2.59 \mathrm{Abc}$ \\
\hline $86 \%$ shading & $11.61 \mathrm{Abc}$ & $12.56 \mathrm{Ac}$ & $14.06 \mathrm{Bcd}$ & $30.88 \mathrm{Aa}$ & $9.12 \mathrm{Bd}$ & $16.14 \mathrm{Ab}$ & $1.84 \mathrm{Bc}$ & $3.86 \mathrm{Aa}$ \\
\hline $93 \%$ shading & $10.47 \mathrm{Bc}$ & $14.20 \mathrm{Ad}$ & $12.54 \mathrm{Bd}$ & $27.80 \mathrm{Ab}$ & $8.97 \mathrm{Bd}$ & $16.49 \mathrm{Ab}$ & $1.63 \mathrm{Bcd}$ & $3.80 \mathrm{Aa}$ \\
\hline Mean & \multicolumn{2}{|c|}{12.21} & \multicolumn{2}{|c|}{19.98} & \multicolumn{2}{|c|}{13.77} & \multicolumn{2}{|c|}{2.32} \\
\hline C.V. $(\%)$ & \multicolumn{2}{|c|}{14.55} & \multicolumn{2}{|c|}{19.50} & \multicolumn{2}{|c|}{27.74} & \multicolumn{2}{|c|}{21.26} \\
\hline
\end{tabular}

*Means preceded by lowercase letters compared in the columns and followed by uppercase letters in the rows, within the same variable, when distinct, differ by Fisher's LSD test $(\mathrm{p} \leq 0.05)$.

In general, it is noteworthy that under the lowest temperature (1st season), the red light was among the treatments that caused the highest values for all variables, not differing, however, from the other light quality treatments for the first three variables (except blue for MSPA), and did not differ under blue light for leaf area. In the second season, the green light was among the treatments with lowest value in all variables.

As for the CPA, the fact that the plants have grown similarly in blue, yellow and especially red light treatments, between the periods of the experiment, even with a difference of over $10{ }^{\circ} \mathrm{C}$, may indicate a strong contribution of these wavelengths in tolerance to low temperatures. There is evidence that the role of the light in acclimation under low temperature is mediated through phytochromes (Olsen et al., 1997), which would positively regulate the expression of stress tolerance genes. Considering that this photoreceptor has absorption peaks at blue, and especially red wavelengths (Majerowicz and Peres, 2004), the lowest loss of low temperature to rice when under these wavelengths is justified.

Regarding CR and MSR, root are poorly studied tissues regarding light response, possibly for being perceived by the shoot, since under natural conditions plant root are underground, that is, essentially in the dark, however Molas et al. (2006), when radiating Arabidopsis seedlings with red light showed that in these tissues there was an expression of a series of genes, which in the shoot were already known under this light spectrum. However, that response associated with temperature is not known.

For leaf area, for which in the first season the colors blue and red showed higher values, this response had already been reported in Ocimum gratissimum Lineu (Martins et al., 2009); whereas in the second season, where the shadings induced the increase in leaf area, this is the behavior normally observed in this condition, since it is necessary for plants to enlarge the photosynthetic surface to maximize the light absorption, which is evidenced in Arachis pintoi and Brachiaria decumbens (Gobbi et al., 2011), but not observed in Sorghum bicolor (Dan et al., 2010). Evidently, this response varies with the species and level of shading, including differences between cultivars of the same species, as in Brachiaria brizantha (Martuscello et al., 2009).

Finally, the highest MSPA under red light can be assigned as a consequence of higher CPA and leaf area, which generally allows the plant a greater photosynthesis capacity and thus accumulation of phytomass. For the cotton plant, the relationship between leaves dry weight and leaf area is such that it is possible to estimate the leaf area by weighing the dry mass, with accuracy and precision, and with an error margin lower than 2\% (Monteiro et al., 2005 ), but no such relationship was tested according to types of light.

Regarding the green light, this has been shown to inhibit growth under conditions of high temperature, as observed in the variables MSPA, MSR and leaf area of the greenhouse experiment and in the variable $\mathrm{CR}$ of both experiments. On the other hand, the green light positively affected the in vitro multiplication of Rubus idaeus L. (Erig and Schuch, 2005). Therefore, these results, of inhibition and stimulation by green light, contrary to its wide use as light for assembly and evaluation of experiments with light, for its supposed neutral, or reduced, action on plants, such as the "safety green light" (Abud et al., 2010).

In the case of cultivars and biotypes, the interaction between the factors temperatures $\mathrm{x}$ cultivar/biotype $\mathrm{x}$ light was observed in only two variables in this study (Tables 2 
and 4), in which the biotype AV 6722 was superior, however, it should be observed, regardless of temperature or light, that this performance may also be attributed to the high initial intrinsic vigor of this biotype, very characteristic in red rice (Agostinetto et al., 2001). In this sense, it can be seen that the studied cultivars and biotypes are similar in behavior regarding temperature and light.

It should be noted that often the cultivars have accesses in common in the germplasm bank from which they were developed, making them similar in some features or in their responses to the environment; now, as for red rice, a study showed that some biotypes showed a certain level of similarity with that cultivated, positioning themselves, in certain characteristics, as intermediaries between groups of cultivars, showing that red rice is in constant evolution and association with the main culture that it infests (Streck et al., 2008), but becoming similar as well due to the normal rate of crossing that occurs between cultivated rice and harmful rice.

Thus, in relation to the similar response against light observed among cultivars and biotypes under the temperature conditions studied, it is suggested that it is probably a characteristic, until then, little selected by genetic improvement, even naturally or by indirect pressure of man in the case of red rice. This indicates that there is a vast way to go about improving plants regarding light perception characteristics related to signaling for tolerance to environmental stresses. It also suggests that further studies should be conducted to identify and relate light to cold tolerance in rice.

\section{Conclusions}

The early development of irrigated rice cultivars and red rice biotypes is stimulated by red light under low temperature, and inhibited by green light under higher temperature;

Low temperature affects the initial development of cultivars and biotypes;

The cultivars and biotypes studied have similar behavior against light and temperature during early development;

Light, in particular in the red wavelength promotes the increase in cold tolerance in rice.

\section{Acknowledgments}

To CAPES and CNPq for the scholarships granted.

\section{References}

ABUD, H.F.; GONÇALVES, N.R.; REIS, R.G.E.; PEREIRA, D.S.; BEZERRA, A.M.E. Germinação e expressão morfológica de frutos, sementes e plântulas de Pilosocereus pachycladus Ritter. Revista Ciência Agronômica v.41, n.3, p.468-474, 2010. http://www.scielo.br/pdf/rca/v41n3/v41n3a21.pdf

AGOSTINETTO, D.; FLECK, N.G.; RIZZARDI, M.A.; MEROTTO, A.; VIDAL, R.A. Arroz vermelho: ecofisiologia e estratégias de controle. Ciência Rural, v.31, n.2, p.341-349, 2001. http://www.scielo.br/pdf/\%0D/cr/ v31n2/a26v31n 2 .pdf

BRASIL. Ministério da Agricultura, Pecuária e Abastecimento. Regras para análise de sementes. Ministério da Agricultura, Pecuária e Abastecimento. Secretaria de Defesa Agropecuária. Brasília: MAPA/ACS, 2009. 395p. http:// www.agricultura.gov.br/arq_editor/file/2946_regras_analise_sementes.pdf

CRUZ, R.P.; MILLACH, S.C.K. Melhoramento genético para tolerância ao frio em arroz irrigado. Revisão Bibliográfica. Ciência Rural, v.30, n.5, p.909-917, 2000. http://www.scielo.br/pdf/cr/v30n5/a31v30n5.pdf

DAN, H.A.; CARRIJO, M.S.; CARNEIRO, D.F.; COSTA, K.A.P.; SILVA, A.G. Desempenho de plantas de sorgo granífero sobre condições de sombreamento. Acta Scientiarum Agronomy, v.32, n.4, p.675-679, 2010. http://www.scielo.br/pdf/asagr/v32n4/a15v32n4.pdf

ERIG, A.C; SCHUCH, M.W. Tipo de luz na multiplicação in vitro de framboeseira (Rubus idaeus L.) 'Batum'. Revista Brasileira de Fruticultura, v.27, n.3, p.488490, 2005. http://www.scielo.br/pdf/\%0D/rbf/v27n3/27803.pdf

GOBBI, K.F.; GARCIA, R.; VENTRELLA, M.C.; GARCEZ NETO, A.F.; ROCHA, G.C. Área foliar específica e anatomia foliar quantitativa do capimbraquiária e do amendoim-forrageiro submetidos a sombreamento. Revista Brasileira de Zootecnia, v.40, n.7, p.1436-1444, 2011. http://www.scielo.br/ $\mathrm{pdf} / \mathrm{rbz} / \mathrm{v} 40 \mathrm{n} 7 / \mathrm{a} 06 \mathrm{v} 40 \mathrm{n} 7 . \mathrm{pdf}$

GRAY, G.R.; CHAUVIN, L.P.; SARHAN, F.; HUNER, N.P.A. Cold acclimation and freezing tolerance (a complex interaction of light and temperature). Plant Physiology, v.114, p.467-474, 1997. http://www. plantphysiol.org/content/114/2/467.full.pdf + html

HASTHANASOMBUT, S.; PAISARNWIPATPONG, N.; TRIWITAYAKORN K.; KIRDMANEE, C.; SUPAIBULWATANA, K. Expression of OsBADH1 gene in Indica rice (Oryza sativa L.) in correlation with salt, plasmolysis, temperature and light stresses. Plant Omics Journal, v.4, n.7, p.400-407, 2011. http://www.pomics.com/hastanasombut_4_7_2011_400_407.pdf

JIAO, Y.L.; LAU, O.S.; DENG, X.W. Light-regulated transcriptional networks in higher plants. Nature Reviews Genetics, v.8, n.3, p.217-230, 2007. http://www.nature.com/nrg/journal/v8/n3/abs/nrg2049.html

MAJEROWICZ, N. Fotossíntese in KERBAUY, G.B. Fisiologia vegetal. São Paulo: Guanabara Koogan, 2004. p.114-178.

MAJEROWICZ, N.; PERES, L.E.P. Fotomorfogênese em plantas. In: KERBAUY, G.B. Fisiologia vegetal. São Paulo: Guanabara Koogan, 2004. p.421-438.

MAJLÁTH, I.; SZALAI, G.; SOÓS, V.; SEBESTYÉN, E.; BALÁZS, E.; VANKOVÁ, R.; DOBREV, P.I.; TARI, I.; TANDORI, J.; JANDA, T. Effect of light on the gene expression and hormonal status of winter and spring wheat plants during cold hardening. Physiologia Plantarum, v.145, p.296-314, 2012. http://onlinelibrary.wiley.com/doi/10.1111/j.1399-3054.2012.01579.x/ abstract; jsessionid=19C403 A0F2662C4A0AFEE994CB26A19A d03t01?deniedAccessCustomisedMessage $=\&$ userIsAuthenticated $=$ false 
MALONE, G.; ZIMMER, P.D.; MENEGHELlO, G.E.; CASTRO, M.A.S.; PESKE, S.T. Expressão diferencial de isoenzimas durante o processo de germinação de sementes de arroz em grandes profundidades de semeadura. Revista Brasileira de Sementes, v.29, n.1, p.61-67, 2007. http://www.scielo. br/pdf/\%0D/rbs/v29n1/09.pdf

MARTINS, A.F.; VIEIRA, E.A.; KOPP, M.M.; LUZ, V.K.; CARVALHO, M.F.; BRANCO, J.S.C; CRUZ, R.P.; CARVALHO, F.I.F.; OLIVEIRA, A.C. Caracterização de famílias mutantes de arroz para tolerância ao frio nos períodos vegetativo e reprodutivo. Bragantia, v.66, n.2, p.227-233, 2007. http://www.scielo.br/pdf/\%0D/brag/v66n2/06.pdf

MARTINS, J.R.; ALVARENGA, A.A.; CASTRO, E.M.; SILVA, A.P.O.; OLIVEIRA, C.; ALVES, E. Anatomia foliar de plantas de alfavaca-cravo cultivadas sob malhas coloridas. Ciência Rural, v.39, n.1, p.82-87, 2009. http://www.scielo.br/pdf/cr/v39n1/a40cr193.pdf

MARTUSCELLO, J.A.; JANK, L.; GONTIJO NETO, M.M.; LAURA, V.A.; CUNHA, D.N.F.V. Produção de gramíneas do gênero Brachiaria sob níveis de sombreamento. Revista Brasileira de Zootecnia, v.38, n.7, p.1183-1190, 2009. http://www.scielo.br/pdf/rbz/v38n7/v38n7a04.pdf

MEROTTO, A.; FISCHER, A.J.; VIDAL, R.A. Perspectives for using light quality knowledge as an advanced ecophysiological weed management tool. Planta Daninha, v.27, n.2, p.407-419, 2009. http://www.scielo.br/pdf/pd/ v27n2/25.pdf

MERTZ, L.M.; HENNING, F.A.; SOARES, R.C.; BALDIGA, R.F.; PESKE, F.B.; MORAES, D.M. Alterações fisiológicas em sementes de arroz expostas ao frio na fase de germinação. Revista Brasileira de Sementes, v.31, n.2, p.254-262, 2009. http://www.scielo.br/pdf/rbs/v31n2/v31n2a31.pdf

MOLAS, M.L.; KISS, J.Z.; CORREL, M.J. Gene profiling of the red light signaling pathways in root. Journal of Experimental Botany, v.57, n.12, p.32173229, 2006.http://jxb.oxfordjournals.org/content/57/12/3217.full.pdf + html

MONTEIRO, J.E.B.A.; SENTELHAS, P.C.; CHIAVEGATO, E.J.; GUISELINI, C.; SANTIAGO, A.V.; PRELA, A. Estimação da área foliar do algodoeiro por meio de dimensões e massa das folhas. Bragantia, v.64, n.1, p.15-24, 2005. http://www.scielo.br/pdf/\%0D/brag/v64n1/23848.pdf
OLSEN, J.E.; JUNTTILA, O.; NILSEN, J.; ERIKSSON, M.E.; MARTINUSSEN, I.; OLSSON, O.; SANDBERG, G.; MORITZ, T. Ectopic expression of phytochrome A in hybrid aspen changes critical day length for growth and prevents cold acclimation. Plant Journal, v.12, p.1339-1350, 1997. http://onlinelibrary.wiley.com/doi/10.1046/j.1365-313x.1997.12061339.x/pdf

PENFIELD, S. Temperature perception and signal transduction in plants New Phytologist, v.179, p. 615-628, 2008.http://onlinelibrary.wiley.com/ doi/10.1111/j.1469-8137.2008.02478.x/pdf

SINGH, S. Growth, yield and biochemical response of rice genotypes to low light and hight temperature-humidy stress. Oryza, v.37, n.1, p.35-38, 2000

STRECK, N.A.; MICHELON, S.; KRUSE, N.D.; BOSCO, L.C.; LAGO, I.; MARCOLIN, E.; PAUlA, G.M.; SAMBORANHA, F.K. Comparação de parâmetros de crescimento e de desenvolvimento de dois biótipos de arroz vermelho com genótipos de arroz irrigado. Bragantia, v.67, n.2, p.349-360, 2008. http://www.scielo.br/pdf/brag/v67n2/a10v67n2.pdf

SVYATYNA, K.; RIEMANN, M. Light-dependent regulation of the jasmonate pathway. Protoplasma, v.249, n.2, p.137-145, 2012. http://link springer.com/content/pdf/10.1007\%2Fs00709-012-0409-3.pdf

VASEVA, I.; TODOROVA, D.; MALBECK, J.; TRÁUNICKOVA, A.; MÁCHACKOVA, I. Mild temperature stress modulates cytokinin content and cytokinin oxidase/dehydrogenase activity in young pea plants. Acto Agronomica Hungarica, v.57, n.1, p.33-40, 2009. https://akkrt.metapress. $\mathrm{com} /$ content/q363 $\mathrm{m} 876653 \mathrm{u} 6374 /$ resource-secured/?target=fulltext pdf\&sid $=5$ p $43 \times 5$ ozegt $0 \mathrm{e} 0 \mathrm{mfhdafno} 4 \mathrm{u} \& \mathrm{sh}=$ www.akademiai.com

YOSHIDA, S. Fundamentals of Rice cropscience. Los Bãnos: International Rice Research Institute, 1981. 269p.

Journal of Seed Science, v.35, n.4, p.510-518, 2013 